\title{
Ortopedi ve Travmatoloji uygulamaları açısından aydınlatılmış onam
}

\section{Informed consent in Orthopedics and Traumatology}

\author{
Emine Ahşen Oktay (Dinç) \\ Türkyaman - Dinç Hukuk Bürosu, Beşiktaş, İstanbul
}

\begin{abstract}
Bu çalışma tıbbi müdahaleyi hukuka uygun hale getiren aydınlatılmış rıza (aydınlatılmış onam) kavramı hakkındadır. Aydınlatılmış rıza aynı zamanda hastanın bilgilendirilme hakkıdır. Aydınlatma, hekim için bir borç, hasta için bir haktır. Hekimin geçerli bir rıza için hastayı, rahatsızlığı, tedavisi ve sonuçları konusunda ayrıntılı olarak aydınlatması gerekmektedir. Hukuken kabul edilebilir bir aydınlatılmış rıza için bilgilendirme ve rıza sürecinde önemli hususların neler olduğu bu çalışmada aktarılmıştır. Ayrıca bu makalede hastanın bilgilendirilmesi yükümlülüğü sonrası hastanın rızasının alınması anlatılmıştır. Bilgilendirme kapsamında; bilgilendirmenin temel özellikleri, bilgilendirmenin zamanı, bilgilendirmeyi yapacak kişi, bilgilendirilecek kişi, bilgilendirmenin şekli, şartı ve ispatı konuları irdelenmiştir. Bilgilendirme sonrası, rızanın temel özellikleri, kapsamı irdelenmiştir. Hasta hakkı ihlali hukuka aykırı eylem olacağından sorumluluğu gerektirmektedir. Geçerli bir aydınlatılmış onam alınmadan yapılan tıbbi müdahale hukuka aykırı olacak (bilgilendirilme hakkının ihlali söz konusu olacaktır) ve sorumluluğu gerektirecektir. Bu kapsamda bir hasta hakkı olan bilgilendirilme hakkının ihlalinde ve/veya rızasız tıbbi müdahale durumunda hastaya ya da hasta yakınlarına karşı hukuki, idari ve cezai olmak üzere hukuksal sonuçları bulunmaktadır. Son olarak da makalemizde aydınlatılmış onam kavramı Yargıtay Kararları ile örnekler verilerek aktarılmıştır.
\end{abstract}

Anahtar sözcülkler: hasta hakkı; aydınlatılmış onam;bilgilendirilme hakkı; aydınlatma yükümü; hukuka uygun aydınlatılmış onam; onam formu

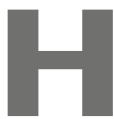

ekim ile hasta arasındaki ilişkinin paternalistik yaklaşımdan uzaklaşılarak hem hekim hem de hastanın karşılıklı hak ve yükümlülükleri olduğu vurgusu ile "sözleşmesel" ilişki kapsamında değerlendirilmeye başlanması sonucu hasta haklarının önemi artmıştır. Çünkü hekimlerin hastaların
At present article deals with informed consent issue that could put medical interventions under legal frame. Informed consent is also the right of patient to be informed. Obligation to inform is an obligation of doctor also a right of patient. Doctors must clarify patient and / or patient relatives about detail information regarding the patient's health problem, therapy and the results of this therapy for valid consent. With this study, we want to explain the meaning of a valid informed consent under legal frame and in this context the important points of informed process and consent process. Also this article describes obligation of informed and then providing approval of the patient. Within scope of the information; the basic principles of the information, the time of the information, person to inform, person to be informed, informed form requirement and the proof of the information were examined. After process of informed of the patient, the basic principles and scope of consent issue were examined. Infringement on patients' rights is caused unlawful medical intervention and require liability. Medical treatment without valid informed consent is unlawful (infringement of right of patient to be informed) and require liability. Our criminal law, private law and also administrative law bear legal consequences to patient and patient relatives when the infringement of right of patient to be informed and/or lack of consent, as a patient's right infringement. Lastly, in our article, informed consent issue is discussed in light of Supreme Court of Appeals decisions.

Key words: right of patient; informed consent; obligation right of patient; burden of clarification; valid informed consent; consent form

- Illetişim adresi: Av. Emine Ahşen Oktay (Dinç), Yönetici Ortak Avukat, Türkyaman - Dinç Hukuk Bürosu, Beşiktaş, İstanbul Tel: 0533 - 6384059 e-posta: ahsendinc@turkyaman-dinc.com

- Geliș tarihi: 11 Aralık 2019 Kabul tarihi: 20 Aralık 2019

sağlığını koruyucu, önleyici, tedavi amacıyla tıbbi endikasyon ve tıbbi standartlara uygun olarak sağIık hizmeti sunmaları yani tıbbi edim yükümlülükleri gibi esas yükümlülükleri yanında hasta haklarına uygun davranmak gibi yan edim yükümlülükleri de mevcuttur. 
Hukuk nezdinde tıbbi edim yükümlülüğüne aykırılık ile yan yükümlülük olan hasta haklarına aykırılık hukuka aykırı eylemin varlığını ortaya çıkaracağı için disiplin sorumluluğunu ve hastalara zarar verici sonuçları olması halinde ise tazminat hukuku ve ceza hukuku açısından sorumluluğunu ortaya çıkaracaktır. Mamafih hekim hastasına her türlü özen ve özveri ile gerekli tıbbi hizmeti sunmuş, hastanın hayatını kurtarmış yahut uzun süredir yaşadığı, hayat kalitesini düşüren sağlık şikâyetlerinin sona ermesini sağlamış olabilir, ama bu süreç içerisinde aydınlatıcı bilgilendirilmeme gibi hasta hakkı ihlali içeren bir davranış söz konusu ise hekimin hukuki sorumluluğu söz konusu olacaktır. Bu meyanda bir hasta hakkı olan bilgilendirilme hakkının önemi ortaya çıkmaktadır.

Diğer yandan, bir tıbbi müdahaleyi hukuk nezdinde kabul edilebilir kılan bazı unsurlar vardır. Bu unsurlardan birinin ya da birkaçının bulunmaması halinde hukuk nezdinde "hukuka aykırı eylem" oluşacaktır. Bu unsurlar tıbbi endikasyon (işlemin hasta için gerekliliği, hasta yararı), tıbbi standart (dünyada kabul edilen kurallara uygun tıbbi hizmet sunumu), yetki (konusunda uzman ve yetkili kişilerce müdahale yapılması) ve rıza (hastanın ve/veya yasal temsilcisinin onayı)'dır. Dolayısıyla hukuka uygun rızanın olmaması hekimin müdahalesini hukuka aykırı hale getirecek, hekimin eylemi hukuk nezdinde adam yaralama/adam öldürme olarak değerlendirilebilecektir.

Bu kapsamda "Aydınlatılmış Onam"; hukuka uygun rızaya ulaşmak için uygulanan sözlü ve yazılı prosedürler bütünüdür.

\section{AYDINLATILMIŞ ONAM KAVRAMI NEYI IFADE EDER?}

“Aydınlatılmış Onam” kavramı, aydınlatıcı bilgilendirme ile tıbbi işleme ilişkin hastanın ve/ veya yasal temsilcisinin onayını yani rızasını almak yani hukuka uygun rızaya ulaşma sürecidir. Kısaca "Aydınlatılmış Onam" kavramını, hasta hakkı olan "bilgilendirilme hakkı" ile hukuka uygunluk nedenlerinden olan "rıza" kavramlarının birleşmesi olarak tanımlayabiliriz.

Hasta hakları, yaşam hakkı ve sağlık hakkını da bütünen bünyesinde barındıran insan haklarının sağlık hizmetlerine yansımasıdır, kişilik hakları ile doğrudan bağlantılıdır. Kişiye sıkı sıkıya bağlı olan haklardandır. Yani devredilemez, mirasçılığa konu edilemez ve sadece ilgili kişi tarafından kullanılan haklardır. ${ }^{[1-3]}$

Anayasa ${ }^{[4]}$ ile koruma altına alınan vücut bütünlüğü, kişinin kendi geleceğini tayin hakkı gibi kişilik hakları "Aydınlatılmış Onam" kavramının temelinde yer alan kişisel değerlerdir.
Kendi geleceğini belirleme hakkı, kişinin kendi farkıılığını ortaya konulma olanağı tanıyarak kendisini gerçekleştirmesine, kendi geleceğini bizzat kendisinin belirlemesine, hayatını etkileyen kararların sorumluluğunu kendisinin taşımasına olanak sağlar. ${ }^{[5-6]}$

Ancak bu hususun da bir sınırı ve istisnası vardır. Kişilik hakları hem kişinin kendisinden hem de üçüncü kişilerden gelebilecek saldırılardan korunan haklardır.

Anayasa ${ }^{[4]} \mathrm{m} .17 /$ f. 2, tıbbî zorunluluklar ve kanunda yazılı hâller dışında, kişinin vücut bütünlüğüne dokunulamayacağı hususunu düzenlemiş, Medenî Kanun ${ }^{[7]}$ m. 24/f. 2'de de, üstün nitelikte özel veya kamusal bir yararın bulunması ya da kanunun verdiği yetkinin kullanılması sebeplerinden birinin varlığı ortaya konulmadığı müddetçe kişilik hakkı zarar gören kişinin rızası olması durumunu hukuka aykırılık olarak düzenlemiştir.

Kişiliğin kişinin kendisinden korunması hem rızanın serbestçe verildiği gibi serbestçe her zaman geri alınabilmesini güvence altına alır hem de kişinin kendisine ya da bir başkasına hiçbir yarar sağlamayacak bir müdahaleye göstereceği rızanın geçerli olmamasını güvence altına alır. ${ }^{[8]}$

Kişinin rızası, kişinin beden bütünlüğüne yönelik herhangi bir müdahalenin hukuka uygun olabilmesi açısından vazgeçilmez bir koşul olarak kabul edildiğinde, bu rızanın gerek rızayı gösterecek kişinin zihinsel yapısı, gerekse açıklama anında herhangi bir dış etken tarafından sakatlanmamış olması gerektiği açıktır. Ancak, sağlıklı bir iradeden söz edebilmemiz için öncelikle, kişinin bu iradesinin konusu ve sonuçları üzerinde tam bir bilgisi olması gerekecektir. Özellikle, tıbbi müdahaleler gibi teknik bir bilgiyi gerektiren, buna karşılık kendisine müdahalede bulunulan kişi üzerindeki sonuçları çok büyük olabilecek eylemlerde, müdahaleye rıza gösterecek kişinin gerek müdahalenin ne şekilde yapılacağı gerekse sonuçları konusunda yeterli şekilde aydınlatılmış olması gerektiği, tartışmasız kabul edilmektedir. ${ }^{[9]}$

Bu bağlamda hukuken geçerli bir aydınlatılmış onam için belli koşulların sağlanması gerekir. Serbest irade ile rıza verilmesi zaruridir. Serbest irade için öncelikle rızanın alınması gereken yetkili kişi yani doğru muhatabın kim olduğunun belirlenmesi, yani rıza vermeye yetkili doğru kişinin tespiti ve bu doğru kişinin tıbbi işlem hakkında doğru şekilde aydınlatılarak bilgilendirilmesi sonrası serbest irade ile rızası alınmalıdır.

Hukukumuzda aydınlatılmış onamın hukuki sonuçlarını düzenleyen özel bir düzenleme mevcut değildir. Türkiye'nin taraf olduğu ve imza attığı Biyoloji ve Tıbbın Uygulanması Bakımından Insan Hakları ve İnsan Haysiyetinin Korunması Sözleşmesi: İnsan Hakları ve Biyotıp Sözleşmesi (kısaca "Biyotıp Sözleşmesi” olarak anılacaktır. $)^{[10]}$, Hasta Hakları Yönetmeliği'nde ${ }^{[11]}$ 
düzenlenen rıza ve aydınlatma hakkına ilişkin hükümler Türk Medeni Kanunu[7], Türk Borçlar Kanunu ${ }^{[12]}$ ve Türk Ceza Kanunu[13] düzenlemeleri kapsamında değerlendirilerek hukuki sonuçları tespit edilmektedir.

\section{Bu kapsamda;}

Biyotıp Sözleşmesi[10] m. 5'te, "Sağlık alanında herhangi bir müdahale, ilgili kişinin bu müdahaleye özgürce ve bilgilendirilmiş bir şekilde muvafakat etmesinden sonra yapılabilir. Bu kişiye, önceden, müdahalenin amacı ve niteliği ile sonuçları ve tehlikeleri hakkında uygun bilgiler verilecektir." düzenlemesi mevcuttur.

Hasta Hakları Yönetmeliği[11] m. 5/d'de "Tıbbi zorunluluklar ve kanunlarda yazılı haller dışında, rızası olmaksızın kişinin vücut bütünlüğüne ve diğer kişilik haklarına dokunulamaz." düzenlemesi mevcuttur.

Hasta Hakları Yönetmeliğgi[11] m. 22'de “Kanunda gösterilen istisnalar hariç olmak üzere, kimse, rızası olmaksızın ve verdiği rızaya uygun olmayan bir şekilde tıbbi ameliyeye tabi tutulamaz." düzenlemesi mevcuttur.

Hasta Hakları Yönetmeliği[11] m. 31'de "Rıza alınırken hastanın veya kanuni temsilcisinin tıbbi müdahalenin konusu ve sonuçları hakkında bilgilendirilip aydınlatılması esastır." düzenlemesi ile aydınlatıcı bilgilendirme sonrası rıza alınması gerektiği, hukuken geçerli bir rıza için aydınlatıı bilgilendirmenin zarureti belirtilmiştir.

\section{HUKUKA UYGUN AYDINLATILMIŞ ONAM NASIL OLUR?}

Hastanın kendi geleceğini belirlemesi açısından önem arz eden ve tıbbi müdahalenin hukuka uygun olması için aydınlatılmış onamın gerekliliğini ve önemini belirttikten sonra "Hukuka uygun aydınlatılmış onam nasıl olmalıdır?" sorusu karşımıza çıkmaktadır.

Tıbbi uygulama sürecinde, hekim ile hasta birlikte hareket etmeli ve birlikte sorumluluk almaları gerekmektedir. Burada bilgilendirme süreci karşılıklı olarak gelişim gösterir. Hasta, hekime sağlık durumu ile rahatsızlığın tüm seyri ile ilgili detaylı bilgi vermeli, hekim de hastasına hastalık, tedavi, teşhis, riskler, tıbbi uygulama süreci vb. konularda kapsamlı olarak bilgi sunmalıdır. Tıbbi uygulama sürecinin teknik yönleri hekim tarafindan organize edilmektedir. Bu sürecin tüm aşamalarında, hekim hastasını tıbbi uygulamalar konusunda bilgilendirip, hastasının bu uygulamalarla ilgili rızasını almalıdır. Hastanın aydınlatılması, hekim ile hastanın ortak işlemleri ile gerçekleşmektedir. ${ }^{[14]}$

Hasta Hakları Yönetmeliği[11]'nde "Rıza"; Kişinin tıbbi müdahaleyi serbest iradesiyle ve bilgilendirilmiş olarak kabul etmesi olarak ifade edilmektedir.
Bu bağlamda hukuka uygun rıza için serbest irade ve bilgilendirilme kavramları önemlidir. Aydınlatılıp bilgilendirilen kişi serbest iradesi ile işleme rıza vermelidir.

Serbest irade sağlanması için öncelikle rıza vermeye yetkili kişinin belirlenmesi gerekir.

Burada ilk olarak sürece başlamadan önce tıbbi işlem yapılacak kişinin yani hastanın yaşı, ayırt etme gücü Medeni Hukuk ehliyet kavramları açısından değerlendirilmeli ve rızanın kimden alınacağı, bu kapsamda bilgilendirme sürecinin kime yöneltileceği (sadece hastaya mı yoksa hasta ile birlikte bir yasal temsilcisine mi?) tespit edilmelidir.

Sonrasında ise rıza aşamasında serbest iradenin bulunması için hastanın ve/veya yasal temsilcisinin baskı altında kalmadan, özgürce sürece dair değerlendirme yapıp, karar vermeleri sağlanmalıdır.

Serbest irade kavramı, yeterli ve uygun bilgilendirmeyi de içermektedir. Çünkü serbest bir iradeden bahsedebilmek için kişinin tıbbi işlem ve süreçler hakkında yeterli derecede bilgilendirilmesi şarttır.

Aydınlatıcı bilgilendirme yapılmadan hukuka uygun rızadan bahsedilemeyeceği için, Hasta Hakları Yönetmeliği'nde de öncelikle bilgi alma hakkı kapsamında bilgilendirme aşaması hakkında düzenlemeler yapılmış, bilgilendirme sonrası rıza aşaması ile "aydınlatılmış onam" süreci düzenlenmiştir.

\section{BILGILENDIRME KIME YAPILMALI, RIZA KIMDEN ALINMALIDIR? YETKILI MUHATAP NASIL BELIRLENECEKTIR?}

Bilgilendirmenin kime yapılacağı hususunda özel bir düzenleme Hasta Hakları Yönetmeliği[11]'nde yazılmamıştır. Ancak bilgilendirme sonrası rızanın kimden alınacağı Yönetmelik ${ }^{[11]} \mathrm{m}$. 24'de düzenlenmiştir. Bu kapsamda ilgili maddeyle bilgilendirme yapılacak kişiyi de dolaylı olarak düzenlenmektedir. Bilgilendirme yapılacak kişi esas olarak hastanın kendisidir. Hasta sürece mutlaka dâhil edilmeli, hastanın küçük veya kısıtlı olduğu durumlarda ise hasta ile birlikte yasal temsilci (veli/vasi) bilgilendirilmelidir.

Bilgilendirme hakkı bir hasta hakkı olduğu için, hasta hakları da kişiye sıkı sıkıya bağlı bir hak olduğu için esas olan bilgilendirmenin hastaya yapılmasıdır. Çünkü kişiye sıkı sıkıya bağlı haklar sadece o kişi tarafından kullanılabilir, devredilemez, mirasa konu olamaz. ${ }^{[1-3]}$ Ayırt etme gücüne sahip küçükler yani 18 yaşının altındaki bireyler ve kısıtılar da kişiye sıkı sıkıya bağlı haklarını kendileri kullanabilirler. Peki, madem sadece o kişi tarafından kullanılıyor, ayırt etme gücü olmayan kiş̧iler bu hakkı kullanamayacak mı? 
Kişinin yüksek yararı bulunan durumlarda kişiye sıkı sıkıya hak niteliğinde olan hakların kişinin görüşü dikkate alınarak kanuni temsilci tarafından kullanılmasını kabul etmek uygun olacaktır. Örneğin kişinin vücut bütünlüğü ile bağlantılı olan sağlık hakkı, yaşam hakkı söz konusu olduğunda hastanın ayırt etme gücünden yoksun olması durumunda hasta yararına yasal temsilcisi onayı ile işlem yapılabilmektedir. Hasta Hakları Yönetmeliği[11]'nin "Hastanın Rızası ve İzni" başlıklı 24. maddesi kişiye sıkı sıkıya bağlı bir hak olan tıbbi müdahaleye karar verme hakkında yasal temsilcinin izninin alınmasını vurgulamıştır. Bu nedenle kişiye sıkı sıkıya bağlı hak değerlendirilmesinde temel kuralın kişi dışında temsilci tarafından kullanılamaması olduğunu ancak kişinin yüksek yararı ilkesi ile ayırt etme gücü bulunmayan durumlarda birey/kişi olarak hastanın mümkün olduğunca sürece görüş ve katkısı da sağlanarak bu hakkın kullanımının yasal temsilci aracılığı ile kullanılabileceğini belirtmek isteriz.

Sağlık hakkı Anayasa ${ }^{[4]}$ 'da düzenlenen üstün bir kişilik hakkı ve insan hakkı olduğu için ve kişinin kendisinden dahi korunduğu için hastanın yararı ilkesini dikkate alarak bu konuda bir istisna getirmiş ve hasta küçük veya mahcur ise velisinden veya vasisinden izin alınır hükmünü düzenlemiştir. Mamafih bu düzenleme kapsamında dahi Hasta Hakları Yönetmeliği[11] m. 24 ile; kanuni temsilcinin rızasının yeterli olduğu hallerde dahi, anlatılanları anlayabilecekleri ölçüde, küçük veya kısıtlı olan hastanın dinlenmesi suretiyle mümkün olduğu kadar bilgilendirme sürecine ve tedavisi ile ilgili alınacak kararlara katılımı sağlanır hükmü getirilmiştir.

Ayrıca kişinin yüksek yararı ve/veya kamu yararı söz konusu olan durumlarda da kişiye sıkı sıkıya bağlı bir hak olan tedaviye başvurma hakkının yakınları ya da kamu görevlileri tarafından vesayet makamına yapılacak bildirim ile kullandırılabileceği ancak "hakimin karar verirken ilgili kişiyi mutlaka dinlemesi gerektiği” Türk Medenî Kanunu (TMK) ${ }^{[7]}$ m. 432 ve devamı maddelerde de düzenlenmiştir. TMK ${ }^{[7]} \mathrm{m} .432$ ve devam hükümleri ile yasa koyucunun da düzenlemeyi yaparken mutlak ve nispi ayrımları dikkate aldığı açıktır.

Burada velayet makamının yahut vesayet makamının kötüye kullanılması durumu ile karşılaşılabilmektedir. Eğer hastanın kararı ile yasal temsilcisinin kararı arasında çelişki var ise veyahut hayatın olağan akışı içerisinde haklı bir neden olmadan rıza verilmiyorsa hekimin tıbben ilgili işlemi hasta yararına yapılması$\mathrm{n}$ uygun gördügüü durumlarda $T M K^{[7]} \mathrm{m} .346$ ve m. 487 kapsamında Sulh Hukuk Mahkemesi'ne başvurup mahkemeden izin alarak hastaya müdahale etme hakkı bulunmaktadır.

\section{Hasta bilgilendirilme hakkından vazgeçebilir mi?}

Yönetmelik[11]'te bilgilendirmenin hastanın kendisine yapılması gerektiği, hastanın kendisi yerine bir başkasının bilgilendirilmesini talep etmesi halinde, bu talep kişinin imzası ile yazılı olarak kayıt altına alınmak kaydıyla sadece bilgilendirilmesi istenilen kişilere bilgi verileceği vurgulanmıştır.

Yönetmelik ${ }^{[11]}$ m. 20'de; “ilgili mevzuat hükümleri ve/veya yetkili mercilerce alınacak tedbirlerin gerektirdiği haller dışında; kişi, sağlık durumu hakkında kendisinin, yakınlarının ya da hiç kimsenin bilgilendirilmemesini talep edebilir. Bu durumda kişinin kararı yazılı olarak alınır. Hasta, bilgi verilmemesi talebini istediği zaman değiştirebilir ve bilgi verilmesini talep edebilir." hükmü düzenlenmiştir.

$\mathrm{TMK}^{[7]} \mathrm{m} .23$ 'te; "Kimse, hak ve fiil ehliyetlerinden kısmen de olsa vazgeçemez. Kimse özgürlüklerinden vazgeçemez veya onları hukuka ya da ahlâka aykırı olarak sınırlayamaz."

Yönetmelik ${ }^{[11]}$ m. 19'da; "Hastanın manevi yapısı üzerinde fena tesir yapmak suretiyle hastalığın artması ihtimalinin bulunması ve hastalığın seyrinin ve sonucunun vahim görülmesi hallerinde, teşhisin saklanması caizdir." hükmü düzenlenmiştir. Bu düzenlemede de tedavisi olmayan bir teşhis ise, hastanın aksi yönde bir talebi yoksa ailesine ya da önceden belirlenen yetkiliye bildirim yapılacağı istisna olarak belirtilmiştir. Maddedeki "hastanın aksi yönde bir talebi bulunmaması" ibaresi de hastanın bilgilendirilme hakkından vazgeçebileceğini göstermektedir.

Tıbbi Deontoloji Tüzüğü[15] m. 14'te; “tabip ve diş tabibi, hastasına ümit vererek teselli eder. Hastanın maneviyatı üzerine fena tesir yapmak suretiyle hastalığın artması ihtimali bulunmadığı takdirde, teşhise göre alınması gereken tedbirlerin hastaya açıkça söylenmesi lâzımdır. Ancak, hastalığın, vahim görülen akıbet ve seyrinin saklanması uygundur." hükmü düzenlenmiştir.

Ancak her şekilde böyle bir durumda "bilgilendirilme hakkından vazgeçmenin" gerekçesinin ilgili hekim tarafından ayrıntılı değerlendirilmesi gerektiği kanaatindeyim. Keza bir hasta hakkı olan bilgilendirilmenin hastanın geleceğini belirleme ilkesi dikkate alındığında kişinin bu haktan vazgeçmesinin istisnai durumlar hariç kabul edilemeyeceği açıktır. İlgili hekimin gerekçeyi değerlendirdikten sonra şüphe içeren hallerde hastaya bizzat bilgilendirme yapılmadığı için işlemi yapmaması gerektiği görüşündeyim.

\section{BILGILENDIRME SÜRECI NASIL OLMALIDIR?}

Hasta Hakları Yönetmeliği[11] m. 15'te bilgilendirmenin kapsamından bahsederek, hastanın yeterli derecede 
aydınlatıldığının kabulü için asgari olarak hangi bilgilerin verilmesi gerektiği belirtilmiştir.

Bilgilendirmenin kapsamı en az aşağıdaki hususları içerecek şekilde olmalıdır;

- Hastalığın muhtemel sebepleri ve nasıl seyredeceği,

- Tıbbi müdahalenin kim tarafından nerede, ne şekilde ve nasıl yapılacağı ile tahmini süresi,

- Diğer tanı ve tedavi seçenekleri ve bu seçeneklerin getireceği fayda ve riskler ile hastanın sağlığı üzerindeki muhtemel etkileri,

- Muhtemel komplikasyonları,

- Reddetme durumunda ortaya çıkabilecek muhtemel fayda ve riskleri,

- Kullanılacak ilaçların önemli özellikleri,

- Sağlığı için kritik olan yaşam tarzı önerileri,

- Gerektiğinde aynı konuda tıbbî yardıma nasıl ulaşabileceği.

$\mathrm{Bu}$ hususların somut hasta kıstası dikkate alınarak düzenlenmesi önemlidir. Bu nedenle her tıbbi işlem için hazırlanan matbu hususlar somut hastanın özellikleri dikkate alınarak değerlendirilmeli ve bilgilendirme taslağı oluşturulmalıdır. Aksi durum bilgilendirme hakkının amacına ve gerekçesine aykırı olacaktır.

Nitekim Yargıtay 13. Hukuk Dairesi 2015/32882 Esas, 2016/24003 Karar, 21.12.2016 Tarihli kararında ${ }^{[16]}$ “. . . davalının ameliyat öncesi muhtemelen hasıl olabilecek sonuç ve komplikasyonlar hakkında hastasını bilgilendirmesi BK. 357. maddesine göre bir zorunluluktur. Öyle olunca dosyaya ibraz edilen onam formu matbu olup, davalı tarafın, davacıyı bu konuda bilgilendirdiği ve gerekçeli açıklamaları yaparak uyardığı hususu ve davacının yeterli derecede aydınlatılıp aydınlatılmadığı, operasyonun komplikasyonlarının bilinmesi halinde dahi bu operasyona davacının rıza gösterip göstermeyeceği konuları dosya içeriği ile anlaşılamamaktadır. Hal böyle olunca bu konudaki davalı delillerinin toplanarak gerekli inceleme ve araştırma yapıldıktan sonra sonucuna göre bir karar verilmesi gerektiği” hususunu vurgulayarak matbu metinlerin hukuka uygun rıza için yeterli olamayacağını belirtmiştir.

Ayrıca bilgilendirme yapılırken bilgilendirme içeriğinde Yönetmelik ${ }^{[11]} \mathrm{m}$. 15'te belirtilen bu hususlar yanında Yönetmelik'te düzenlenen tıbbi işlem sürecinde önem arz eden diğer hasta hakları (tedavinin ret hakkı ve sınırları, hastanın aksine bir talebi yoksa tıbbi kayıtlarını talep halinde hasta ve yasal temsilcisi ile paylaşılacağı vb.) ile bilgilendirme hakkı kapsamında bu bilgilendirmenin hastaya yapıldığı, bu bilgilendirme amacının hastayı ürkütmek olmayıp sürece dâhil etmek olduğunun, geçmiş hastalıklar ve tedavisi, kullandığı ilaçlar gibi tıbbi öyküsü hakkında hekime bilgi vermesinin önemli olduğunun, şikayeti ile ilgili olarak bir başka hekimden de sağlık durumu hakkında ikinci bir görüş alma hakkı bulunduğu ve benzeri hususların vurgulanması gerektiği kanaatindeyim.

Yine Yönetmelik ${ }^{[11]}$ m. 24 düzenlenmesi dikkate alınarak, tedavi sonrası süreç ile ilgili hastadan beklenen hususlar (ne kadar süre kontrole gelmesi gerektiği, yeme, içme, spor, yıkanma hususlarında ne kadar süre nelere dikkat etmesi gerekebileceği gibi hususlar) hakkında da bilgilendirme yapılmalıdır.

Yönetmelik ${ }^{[11]} \mathrm{m}$. 18'de aydınlatarak bilgilendirme aşamasında bilgi verme süreci hakkında düzenlemeler yapılmıştır. Bu kapsamda;

\section{Bilgilendirme İçeriği-Yöntemi}

Yönetmelik ${ }^{[11]} \mathrm{m}$. 15'te belirtilen hususlar serbest iradeyi kullanmayı sağlayacak bir içerik ve yöntem ile kişiye aktarılmalıdır.

- Bilgilendirmenin sade, tereddüt ve şüpheye yer vermeden, somut hastanın sosyal ve kültürel düzeyine uygun, somut hastanın anlayabileceği şekilde yapılması vurgulanmıştır. Tıbbi terimlerden uzak durularak yalın bir anlatımla bilgilendirme yapılması önemlidir.

Aydınlatılmış onam, hastanın kendisine yapılacak işlemleri onayladığını belirten imzasının alınmasından farklıdır. Temel amaç hastaya bilgi vermek ve bu bilgiyi anlamasını sağlamaktır. Bu nedenle form imzalatılmasından önce yapılması gereken, hastanın kendi kültürüne ve eğitim düzeyine uygun biçimde bilgilendirilmesinin sağlanmasıdır. Ayrıca hastanın verilen bilgileri anlamasının sağlanması ve anladığının denetlenmesi gerekir. ${ }^{[17]}$ Kişinin zekâsı, eğitim ve kültür seviyesi, yaşam standardı değişiklik göstereceğinden "somut hasta kıstası" önemlidir.

- Bilgilendirme yapılırken hasta soru sorması hususunda cesaretlendirilmeli, soru işaretleri mümkün olduğunca giderilmelidir. Özgür iradeyi etkileyecek davranışlardan kaçınılmalıdır.

Tıbbi duruma ilişkin olarak bilgilendirme yapılırken hastanın kafasında karışıklığa, güvensizliğe yol açmamak son derece önemlidir. Zira bilgi asimetrisi ve hastalık sebebiyle dezavantajlı durumda olan hasta, serbestçe iradesini oluşturup kararını verirken, durumunu mümkün olduğunca net biçimde anlamalı, önünü görebilmelidir. Hastanın içinde bulunduğu tıbbi koşullar sebebiyle özellikle kırılgan ve hekime bağımlı, onun bakımına ve ilgisine muhtaç olduğu durumda iletişim yolu seçilirken göz ardı edilmemelidir. ${ }^{[8-18]}$

Özgür iradeyi olumsuz etkileyecek şeylere örnek olarak bilgiyi dağınık ve çok hızlı şekilde vermek, hastanın 
düşünmesi için çok az zaman tanımak, soru sormasına izin vermemek gibi hususlar belirtilebilir.

Özgür iradenin sağlanması için hekimin hastasıyla hastasını tanıma amaçlı iletişim kurması, hastanın problemine tıbbi standart uygulamalar kapsamında çözüm ararken hastanın sosyal ve özel yaşantısındaki hususlarında (mesleği, düzenli alışkanlıkları gibi) olumlu olumsuz etkisini tartması, bilgilendirmeyi hastanın anlayabileceği bir dil, yöntem ve şekilde veriyor olması gerekir. Kişinin süreci anlaması sağlandığı zaman verilen bilgilendirme, aydınlatma içeren bir bilgi olacak ve kişinin kendi geleceği hakkında karar verme hakkına zarar verilmeyecektir.

\section{Bilgilendirme Yükümlülüğünün Ortadan Kalktığı, Kapsamının Daraldığı-Genişlediği Durumlar}

Acil ve hayati tehlike durumlarında hastanın rızası aranmaz, bu kapsamda hekimin bilgilendirme yükümlülüğü de ortadan kalkmaktadır.

Biyotıp Sözleşmesi[10] m. 8'de, "acil bir durum nedeniyle uygun muvafakat alınamadığında, ilgili kişinin sağlığı için gerekli olan herhangi bir tıbbi müdahale derhal yapılabilir." hükmü düzenlenmiştir.

Hasta Hakları Yönetmeliği[11] m. 24'te; “Hastanın rızasının alınamadığı hayati tehlikesinin bulunduğu ve bilincinin kapalı olduğu acil durumlar ile hastanın bir organının kaybına veya fonksiyonunu ifa edemez hale gelmesine yol açacak durumun varlığı halinde, hastaya tıbbi müdahalede bulunmanın rızaya bağlı olmadığı, bu durum kayıt altına alınarak hastaya gerekli tıbbi müdahale yazılacağı" düzenlenmiştir. Ancak mümkünse hastanın orada bulunan yakını veya kanuni temsilcisi; mümkün olmadığı takdirde de tıbbi müdahale sonrasında hastanın yakını veya kanuni temsilcisinin bilgilendirileceği belirtilmiştir.

Aydınlatmanın kapsamı, genel geçer bir kural koyarak değil, somut olayın özelliklerine göre ortaya konmalı ve bu bakımdan hastanın ne kadar bilmek istediği ve bu bilgilerden ne kadarını kaldırabileceği göz önünde tutulmalıdır. Bu noktada soyut bir varlık değil, bizzat somut hasta ele alınır. Genel olarak makul bir insanın ne kadar bilgi almak isteyeceği şeklinde genel bir ölçüt belirlenemez. Ölçü somut hastadır. Aydınlatmanın içeriği hekimin takdirine bırakılmamıştır. Bu husus, objektif kıstaslara ve hastanın beklentilerine göre belirlenir. ${ }^{[19]}$

íkinci olarak aydınlatmanın kapsamı müdahalenin gerekliliğine ve rizikonun ağırlı̆̆ına göre belirlenecektir. Böylece müdahale gerekliliğindeki azalma, daha az ihtimal kapsamında olan sonuçlar konusunda dahi aydınlatmayı gerekli kılmaktadır. ${ }^{[19]}$
Bu kapsamda somut hasta kıstası dikkate alınarak kişinin aydınlatılacak konu hakkında bilgi sahibi olduğu durumlarda, tedavi amacı olmayan ancak psikolojik ve sosyal endikasyonu olan müdahalelerde aydınlatma yükümlülüğü kapsamının geniş tutulduğu öğretide kabul edilmektedir.

\section{Bilgilendirme Şekli}

Esas olan bilgilendirme şeklinin sözlü bilgilendirme olduğu vurgulanmıştır.

Bu husus aydınlatılmış onam sürecinin hastanın tıbbi sürece dâhil edilerek hasta ile hekim arasındaki güven ilişkisinin gereği olduğunun göstergesidir.

Aydınlatılmış Onam alma sürecini kolaylaştırıcı çeşitli araçlar kullanılabilir. Bunlar arasında en yaygın olanları bilgilendirici broşürler/kitapçıklardır. Bunların yanı sıra, çeşitli tablolar içeren kartlar veya konu ile ilgili kimi önemli bilgileri içeren CD'lerden de yararlanılabilir. Burada önemle üzerinde durulması gereken nokta, bunların sadece aydınlatılmış onam alma ve genel olarak hasta ve sağlık ekibi arasındaki iletişim sürecine yardımcı gereçler olmasıdır. Tek başına bu araçların kullanılması hiçbir zaman hasta için özgün ve insani bir nitelik taşıması gereken onam alma eyleminin yerine geçmez. Hekim (veya sağlık ekibinin diğer üyeleri) iletişimin kimi açılardan daha kolay yürütülebilmesi için bu araçlardan yararlanabilir, ancak bilgilendirme hasta birey ile uygun bir ortamda ve yeterli süre ayırarak yüz yüze görüşsme ile yapılmalıdır. Bu koşul sağlanmadan alınmış onamlar geçersiz kabul edilmelidir. ${ }^{[17]}$

Bilgilendirme uygun ortamda ve hastanın mahremiyeti korunarak yapılmalıdır.

\section{Bilgilendirme Kim Tarafından Yapılmalıdır?}

Yönetmelik ${ }^{[11]}$ 'te bilgilendirmenin, tıbbi işlemi yapacak sağlık meslek mensubu tarafindan yapılması gerektiği, istisnai hallerde bilgilendirme yeterliliğine sahip başka bir sağlık meslek mensubu tarafından yapılabileceği vurgulanmıştır.

\section{Bilgilendirme Hakkından Vazgeçilebilir mi?}

Yönetmelik[11]'te bilgilendirmenin hastanın kendisine yapılması gerektiği, hastanın kendisi yerine bir başkasının bilgilendirilmesini talep etmesi halinde, bu talep kişinin imzası ile yazılı olarak kayıt altına alınmak kaydıyla sadece bilgilendirilmesi istenilen kişilere bilgi verileceği vurgulanmıştır.

Ancak böyle bir durumda "bilgilendirilme hakkından vazgeçmenin" gerekçesinin ilgili hekim tarafından ayrıntılı değerlendirilmesi gerektiği kanaatindeyim. Keza bir hasta hakkı olan bilgilendirilmenin hastanın 
geleceğini belirleme ilkesi dikkate alındığında kişinin bu haktan vazgeçmesinin istisnai durumlar hariç kabul edilemeyeceği açıktır. İlgili hekimin gerekçeyi değerlendirdikten sonra şüphe içeren hallerde hastaya bizzat bilgilendirme yapılmadığı için işlemi yapmaması gerektiği kanaatindeyim.

\section{Bilgilendirme Zamanı}

Acil durumlar dışında, bilgilendirmenin hastaya makul süre tanınarak yapılacağı düzenlenmiştir.

Makul sürenin yapılacak tıbbi işlem ile somut hasta kıstasına göre belirlenmesi gerekmektedir. Buradaki amaç hastanın vereceği/verdiği kararı çevresi ile, ailesi ve aile hekimi ile paylaşması, verdiği karardan emin olması, bilgilendirme anında gelmeyen fakat daha sonra aklına gelebilecek soruların cevaplarını alabilmesidir.

Makul sürenin ne olduğu her tıbbi müdahalenin niteliğine ve ciddiyetine göre değişik, Medeni Kanun ${ }^{[7]} \mathrm{m}$. 2 gereğince dürüstlük kuralına göre belirlenmelidir. ${ }^{[8]}$

Aydınlatma ne çok erken ne de çok geç yapılmamaIı, zamanında yapılmalıdır. Hekim aydınlatma konuşmasını, zaman baskı altında yapmamalı, hastasına da karar verme baskısı uygulamamalıdır. Acil bir durum söz konusu olmadığı sürece, hastaya düşünmesi için makul ve uygun bir süre tanımalıdır. Kural olarak aydınlatma, ameliyattan bir gün öncesinden daha geç yapılmamalıdır. Öğretide de bu konuda her hal ve şart için geçerli olabilecek genel bir kural konulmasının olanaksız olduğuna işaret edilmektedir. ${ }^{[19]}$

Hasta Haklarına ilişkin Avrupa Statüsünde ${ }^{[20]}$; "Sağlık hizmeti verenler ve profesyoneller (meslek sahipleri) gerçekleşecek herhangi bir ameliyat veya tedaviye ilişkin tüm bilgileri-riskleri, sıkıntıları, yan-etkileri ve alternatif durumları ile ilgili bilgiler dahil olmak üzere-hastalara vermek zorundadır. Bu bilgi önceden (en azından 24 saat önce) verilmeli ki hasta durumu konusunda kendi seçimini yapabilsin." denilerek bu süre en az 24 saat olarak belirtilmiştir.

Riski fazla olan büyük cerrahi işlemler ile tedavi amaCı taşımayan özellikle yazılı rıza gereken işlemler açısından bu sürenin en az 24 saat ile 48 saat aralığında olması gerektiği kanaatindeyim.

\section{RIZA SÜRECi}

Aydınlatıcı bilgilendirme sonrası rıza sürecine geçilecektir.

Hasta Hakları Yönetmeliği'nde "Rıza", kişinin tıbbi müdahaleyi serbest iradesiyle ve bilgilendirilmiş olarak kabul etmesi olarak tanımlanmıştır.

\section{Rıza İçeriği}

Hukuken geçerli bir rıza için hastanın tıbbi işlem ve süreç hakkında aydınlatılarak bilgilendirilmesi gerektiğinden rıza içeriğinde bilgilendirilen hususları değerlendirip, uygun bulduğu, tıbbi işlemi kabul ettiği belirtilmelidir.

Hukuka ve ahlaka aykırı bir rıza alınamayacağı düzenlenmiştir.

\section{Rıza Şekli}

Rızanın mevzuattın öngördüğ̈̈ istisnalar dışında şekle bağlı olmadığı, yani sözlü ya da yazılı alınabileceği belirtilmiştir. Mevzuattaki bu istisna vurgusu herhangi bir işleme ilişkin yazılı rıza alınması gerektiğinin özel olarak düzenlendiği hususlardır. 1219 sayılı Kanunda büyük cerrahi ameliyeler açısından, Rahim Tahliyesi ve Sterilizasyon Hizmetlerinin Yürütülmesi ve Denetlenmesine iliş̧kin Tüzük, Organ ve Doku Nakli Hizmetleri Yönetmeliği, İlaç ve Biyolojik Ürünlerin Klinik Araştırmaları Hakkında Yönetmelik yazılı rıza alımına ilişkin hükümler içeren hukuki düzenlemelerden bazılarıdır.

Rıza herhangi bir şekle bağlı olmamakla birlikte bilgilendirme yapılarak rıza alındığı, yapılan bilgilendirmenin Yönetmelik ${ }^{[11]}$ içeriğini içerdiği hususunu ispat için en kolay yöntem bilgilendirme ve bu bilgilendirme uyarınca alınacak rızanın yazılı olmasıdır.

Yargıtay 15. Hukuk Dairesinin 2018/5523 Esas, 2019/801 Karar, 26.02.2019 Tarihli kararında. ${ }^{[16]}$ yazılı bir onam formu olmasına rağmen hasta tarafindan eklendiği belirtilen beyanda hastanın imzası parafı olmadığı, hastanın el ürünü de olmadığı için ispatlanamadığı ve aydınlatmanın yeterli olduğundan bahsedilemeyeceği belirtilmiştir.

"Hasta Bilgilendirme ve Rıza Formunda "Kaşlarımdaki asimetrinin kısmen düzeltilebileceği bana anlatıldı. Ayrıca kaşlarımın fazla kaldırılmasını istemiyorum" yazısının birleşen dosya davacısı. . . 'ın eli ürünü olmadığı açıklanmıştır...iş sahibi yararına sonuç vermediği gibi, davacıdan alınan aydınlatılmış onam formuna eklenen, "Kaşlarımdaki asimetrinin kısmen düzeltilebileceği bana anlatıldı. Ayrıca kaşlarımın fazla kaldırılmasını istemiyorum" şeklinde ifade edilen kısım, iş sahibi tarafindan yazılıp paraf edilmemiştir. Bu haliyle aydınlatmanın yeterli olduğundan söz edilemez..."

Yönetmelik[11] m. 26'da yazılı şekil şartı mevzuatta belirtilen uygulamalar ile uyuşmazlığa sebep olması muhtemel olan uygulamalar için Yönetmelik ${ }^{[11]} \mathrm{m} .15$ kapsamında belirtilen bilgileri içeren "rıza formu" hazırlanacağı belirtilmiştir. 
Burada ilk olarak sözlü olarak rıza formu içeriğinin hastaya ve/veya yasal temsilcisine anlatıldıktan sonra imzaları alınacağı vurgulanmıştır.

Rıza formu alınan durumlarda iki nüsha olarak imza altına alınacağı ve bir nüshanın hasta dosyasına eklenirken, diğer nüshanın hastaya/temsilcisine teslim edileceği belirtilmiştir. Formu hasta ve/veya yasal temsilcisi yanında karşı taraf olarak bilgilendirmeyi yapan ve tıbbi işlemi yapacak olan sağlık meslek mensubu da imzalayacaktır.

\section{ORTOPEDI VE TRAVMATOLOJI UYGULAMALARINDA AYDINLATILMIŞ ONAM}

Ortopedi ve Travmatoloji uzmanlık alanı cerrahi branşlar içerisinde tıbbi malpraktis iddialarının sık göründüğü branşlardan biridir.

Özellikle travma vakalarında, ortopedik olgulara göre hastaların beklentileri daha fazla olabilmektedir. Keza ortopedik olgularda hastalar, kalça veya diz artrozunda olduğu gibi hastalıklar nedeniyle zaten bozulmuş bir fonksiyona sahiptir. Geçirdikleri cerrahi müdahale sonrası mükemmel sonuç yerine, mevcut durumlarına göre daha iyi derecede bir işlevselliğe sahip olmaları hastaları memnun etmek için yeterli olabilmektedir. Ancak travma sonucunda hastalar sahip oldukları normal fonksiyonlarını kaybetmektedir. Hastaların beklentilerini buna göre oluşturmaması şikayet nedeni olabilmektedir. Travma tedavisi sonrasında tıp kurallarına göre mükemmel sonuçlar elde edilse de, anatomik bütünlüğün bozulduğu ortopedik travma olgularında yaralanma öncesi fonksiyonların tam olarak kazanılamaması olağan bir durumdur. ${ }^{[21]}$

Yine Ortopedi ve Travmatoloji uzmanlık alanı; hassas gruplar içerisinde yer alan 18 yaş altı ve ayırt etme gücü açısından sorun olan 65 yaş üzeri bireyler açısından da travma vakalarının sık göründüğü bir branştır. Diğer yandan yaş ve ayırt etme gücü açısından bir ayrım yapılmadan tüm birey grupları açısından ise travma vakalarının yoğun görüldüğü bir branştır. Uzuvların kaybedilmesi ya da fonksiyonlarında azalma olması yapılan tıbbi müdahale Ortopedi ve Travmatoloji alanındaki uygulamalar açısından başarılı olsa da anatomik bütünlük bozulmakta, hastaların hayatını olumsuz etkileyen sonuçlar ortadan kalkmamaktadır.

Ayrıca Ortopedi ve Travmatoloji branş alanındaki vakalar ve yapılan işlemler, hastanın mesleki faaliyetlerini etkileyebilecek sonuçlar yaratabilmektedir. Örneğin bir balerinin artık dans edememesi, sporcunun bir süre spor faaliyetlerinde bulunamaması gibi.

Ek olarak, yüksek riskli Ortopedi ve Travmatoloji branş alanındaki yaralanmalar beraberlerinde yol açabilecekleri damar, sinir hasarı nedeniyle özel dikkat, ilgi, yaklaşım ve hız gerektiren potansiyel komplikasyon taşıyan yaralamalar söz konusu olabilir. ${ }^{[22]}$

Sinir kesisi, hareket kısıtlılığı, kompartman sendromu gibi komplikasyon ihtimalleri tıbbi işlem öncesi bilgilendirmenin geniş kapsamlı yapılmasını gerektirebilecek sonuçlardır.

Bunlar yanında Ortopedi ve Travmatoloji branş alanındaki vakalarda yaşam kalitesini, konforunu arttırmakla birlikte tıbbi müdahale yapılmadan da kişilerin hayatına devam edebileceği şikâyetler söz konusu olabilmektedir. Aciliyet içermeyen tıbbi müdahalelerde hekimin bilgilendirme yükümlülüğünün kapsamı genişlemektedir ve ayrıntılı bir bilgilendirme yapılması gerekmektedir. Bu nedenle ayrıntılı bilgi vermesi söz konusu olduğu için hasta şahıs bütünlüğüne ilişkin tıbbi müdahalenin az zaruri olması nedeniyle tedaviden vazgeçip, günlük hayatını hasta şekilde sürdürebilmektedir.[23]

Yukarıda da bölümlerde izah ettiğimiz üzere bilgilendirmenin kapsamı kişiye ve kişinin özelliklerine göre ve tıbbi uygulamalar sonucunda oluşabilecek riske, zarara göre değişiklik gösterebilir. Örneğin bir piyanistin parmaklarını kullanamaması, bir fotomodelin yüzünde yara izinin kalabileceği mutlak surette hastaya bildirilmelidir. Başka bir söylemle, aydınlatmanın kapsamının bazen hastanın kişisel özellikleri ve tıbbi uygulamanın türü tayin eder. ${ }^{[14]}$

Ayrıntılı olarak izah ettiğimiz üzere, Aydınlatılmış Onam Anayasa ${ }^{[4]}$ 'da düzenlenen kişilik haklarından olan kişinin kendi geleceğini tayin hakkının gereği hasta ile hekim arasındaki güvene dayalı sözleşmesel ilişkide hastanın hekim karşısında bilgi asimetrisinin ortadan kaldırılması ve aydınlatıcı bilgilendirme sonrası sürece hâkim olarak kararına ilişkin irade beyanında bulunması için gerekli olduğundan, hukuka uygun bir aydınlatılmış onamın nasıl olması gerektiğini belirtirken branşlara göre ayrım yapmak çok doğru olmayacaktır. Ancak Ortopedi ve Travmatoloji uzmanlık alanının özellikle hastanın uzuvlarında araz bırakacak komplikasyonlara sebebiyet veren uygulamaların çok olduğu bir uzmanlık dalı olması, hassas gruplar olan çocukluk ve yaşlılık dönemindeki bireylerin başvurularının yoğun olduğu bir uzmanlık dalı olması sebebiyle ağırlıklı olarak "aydınlatma yükümlülüğünün kapsamının geniş olduğu " bir alan olduğundan bahsedebiliriz.

Hukuken geçerli bir tıbbi müdahaleden bahsedebilmek için hukuka uygun bir rızanın bulunması gereklidir. Hekimin aydınlatma yükümlülügü ise hukuka uygun rızanın koşullarından biridir.

Öncelikle Hasta Hakları Yönetmeliğ [11] m. 24 hükmü uyarınca rıza açıklama ehliyeti açısından ergin olmayan ya da ayırt etme gücü açısından sorun olan 
hastaların yasal temsilcisi ile birlikte bilgilendirme sürecine ve tedavisi ile ilgili alınacak kararlara katımı hususuna dikkat edilmelidir. Anlatılanları anlayabilecekleri ölçüde, küçük veya kısıtlı olan hastanın dinlenmesi önemlidir.

Rızanın serbest irade ile verilmesi gerektiğinde bilgilendirme sürecinde serbest iradenin sağlanması için gerekli hususlara dikkat edilmelidir.

Bilgilendirme sürecinde hastanın geçmiş tıbbi öyküsü, yaşam tarzı, sosyal-kültürel durumu dikkate alınarak o hastaya özel bir bilgilendirme yapılmalıdır.

Hastanın tedavi öncesi başvuru nedeni dışındaki rahatsızlıkları kesinlikle göz ardı edilmemelidir. Örneğin romatoid artrit olan bir hastada kaynamanın gecikebileceği hastaya söylenmeli veya diyabeti olan bir hastada olağandışı yara sorunlarının ortaya çıkabileceği bildirilmelidir. Müdahale öncesinde sistematik yaklaşımda bulunulmalıdır. ${ }^{[21]}$

Hasta Hakları Yönetmeliğ[ ${ }^{[11]}$ m. 15'te belirtilen kapsamda soru-cevap şeklinde aydınlatıcı bilgilendirme yapılmalıdır. Keza hastanın tüm soru işaretlerinin giderildiği, tıbbi terimlerden uzak, anlayabileceği dilde yapılan bilgilendirmeler, aydınlatıcı kabul edilmektedir. Temel kural ise ancak aydınlatıcı bilgilendirme sonrası hastanın serbest iradesi ile karar verebileceği yönündedir.

Hastaya bu işlemi size neden uygulamayı öneriyoruz? İşlemi nerede, nasıl, ne kadar tahmini bir sürede yapacağız? Tedavi öncesi ve sonrası sizden beklediğimiz hususlar nelerdir? Bu işlemi yapmazsak yerine yapabileceğimiz alternatif bir işlem var mı? Bu iki süreç arasında fayda ve risk dengesi nedir? Işlemin yan etkisi, komplikasyonu var mı? Tedavinin başarı olasılığı nedir? Tedaviyi reddederseniz neler ile karşılaşabiliriz? Sorularının hastanın aklında hiçbir şüphe ve soru kalmayacak şekilde, hasta korkutulmadan ve baskı altında bırakılmadan karşııklı sözlü görüşme ile cevaplanması önemlidir.

Unutulmamalıdır ki bilgiyi dağınık ve hızlı vermek, az zaman tanımak, hastanın soru sormasına izin vermemek, bilgiyi eksik vermek serbest iradeyi etkileyecek ve verilen rıza hukuka uygun bir riza olmayacaktır.

Verilen bilginin hasta ve/veya yasal temsilcileri tarafından anlaşılıp anlaşıımadığının teyidi yükümlülüğü ilişkinin profesyonel tarafı olan hekim uhdesinde olduğu kabul edilmektedir.

Bu nedenle sözlü aydınlatma sonrası hekimin hastasının aydınlatıcı bilgilendirme aşamasına gelip gelmediğini bazı sorular sorarak teyit etmesi önemlidir.

- Size önerdiğimiz tedaviyi anlatabilir misiniz?

- Neden bu tedaviye karar verdiniz?
- Önerilen tedavinin yararı ve risklerini anlatabilir misiniz?

- Tüm bu hususlar sonrası bize iletmek istediğiniz merak ettiğiniz bir husus, sorunuz var mıdır?

Bilgilendirme süreci hekim ile hasta arasındaki güven ilişkisinin ayrılmaz parçası olması sebebiyle sözlü bilgilendirme esas olan yöntemdir. Hukuki düzenlemelerde de bilgilendirme sürecinin yazılı yapılması gerektiğine yönelik herhangi bir düzenleme bulunmamaktadır. Ancak olası bir şikayet incelemesi ya da yargı sürecinde "aydınlatıcı bilgilendirme yapıldığının" ve serbest irade ile rıza verildiğinin ispat yükü hekim uhdesinde olduğundan sözlü bilgilendirme sonrası bu sürecin yazılı metne aktarılmasını şiddetle tavsiye ediyorum.

Nitekim Yargitay 13. Hukuk Dairesi'nin 2017/8664 Esas, 2019/6410 Karar, 22.05.2019 Tarihli kararında ${ }^{[16]}$,

"Dosyadaki bilirkişi heyeti raporunda da açıklandığı gibi, aydınlatılmış onam formunda yapılan cerrahi girişime ait spesifik herhangi bir tıbbi bilgi bulunmadığı, hasta hakları yönetmeliğine ve etik ilkelere göre hastaya yeterince sözlü bilgi verilip verilmediği konusunda da ispatın olmadığı gözlemlenmiştir. Mahkemece, aydınlatılmış onamda ispat külfetinin hekim ya da hastanede olduğu gözetilerek davalıların sorumIu olduğu kabul edilmeli ve hasıl olacak sonuca uygun bir karar verilmeliyken, yanılgılı değerlendirmeyle, hüküm tesisi usul ve yasaya aykırıdır." denilerek işleme ilişkin spesifik tıbbi bir bilgi bulunmadığı için onam formunun geçerli olmadığı, yeterli sözlü bilgilendirme için başka bir delil bulunup bulunmadığının Yerel Mahkeme tarafından incelenmesi gerektiği hususu açıcça vurgulanarak, ispat yükünün hekimde olduğu belirtilmiştir.

Bu kapsamda sözlü ve yazılı bilgilendirme sürecinde hekimin ilk olarak hastasını tanımaya çalışması, mesleği, düzenli alışkanlıkları gibi tedavi süreci sonrası ortaya çıkabilecek komplikasyonlar sonrası değişebilecek/ etkilenebilecek durumları tespit ederek bunları yazılı onam formuna aktarması, bu kapsamda bilgilendirme sürecinde hastanın hekime sorduğu bazı özellikli soruları yazılı forma aktarması matbu bir form ile bilgilendirme yapılmadığı ve serbest irade ile rıza alındığını gösterecektir.

Yoğunluk, yeterli süre bulunmaması ve sair sağlık işletmeciliği uygulamaları nedeniyle uygulamada matbu formların hazırlanması ve hastanın önüne bu formların imza için sunulması kabul edilebilir. Ancak bu formlar içeriğinin "somut hastaya" göre özelleştirilebilecek, bilgilendirme sürecinde ekleme ve revizyon yapılabilecek nitelikte olması önemlidir.

Tüm bu hususları Yargıtay kararları kapsamında incelediğimizde Yargıtay'ın yerleşik kararlarında tıbbi 
hata olmasa da hasta hakkına aykırılık oluşturan bilgilendirilme hakkının yani yeterli ve geçerli aydınlatılmamış onam bulunmaması durumunu hukuka aykırılık olarak belirterek tazminata hükmedilmesi gerektiği yönünde kararları bozduğu görülmektedir.

Yargıtay 13. Hukuk Dairesi 2015/11729 Esas, 2016/9861 Karar, 07.04.2016 Tarihli kararında;

"hastanın düşerek kolunu kırması sonrası Ortopedi ve Travmatoloji doktorunun muayenesi sonucu kendisine iğne yapıldı̆̆ını ve iğne yapılır yapılmaz o anda să̆ ayak bileğinin düştüğ̈̈nü, topallamaya başladığını, bacağında oluşan güç kaybı nedeni ile davalının sorumlu olduğunu ileri sürerek, fazlaya dair hakkı saklı kalmak kaydıyla, maddi ve manevi tazminat talep ettiği kararda, dosyaya kazandırılan adli tıp raporu ve üniversite öğretim üyelerinden oluşan bilirkişi heyetinden alınan raporda olayın komplikasyon sınırları içinde kaldığı belirtilerek davalının sorumlu olmadığı bildirilmiştir. Ayrıca bilirkişi raporunda, işlemi yapan doktorun işlemle ilgili hastasın bilgilendirmesinin tıbbi kurallara uygun olduğu da belirtilmiștir."

Yerel Mahkemede bilirkişi raporu doğrultusunda davayı reddetmiştir. Ancak Yargıtay incelemesinde,

“ Biyotıp Sözleșmesinin 5. maddesinde "Rıza” konusu düzenlenmiş ve "Sağlık alanında herhangi bir müdahale, ilgili kişinin bu müdahaleye özgürce ve bilgilendirilmiş bir şekilde muvafakat etmesinden sonra yapılabilir. Bu kişiye, önceden, müdahalenin amacı ve niteliği ile sonuçları ve tehlikeleri hakkında uygun bilgiler verilecektir. Ilgili kişi muvafakatini her zaman serbestçe geri alabilecektir." düzenlemesiyle rızanın kapsamı belirlenmiş ve Dairemizin yerleşik uygulamalarına paralel düzenlemeler getirilmiştir. Salt yapılacak işleme rıza göstermek yeterli değildir. Ayrıca, komplikasyonların da izah edilmesi gerekmektedir. Ancak bu rizanın da az yukarıda vurgulandı̆̆ı üzere aydınlatılmış rıza olması gerekir. Nitekim Hekim Etiği Yönetmeliği'nin 26. maddesinde düzenleme yapılmıs ve "Hekim hastasını, hastanın sağlık durumu ve konulan tanı, önerilen tedavi yönteminin türü, başarı şansı ve süresi, tedavi yönteminin hastanın sağı̆ğı için taşıdığı riskler, verilen ilaçların kullanılısıı ve olası yan etkileri, hastanın önerilen tedaviyi kabul etmemesi durumunda hastalığın yaratacağı sonuçlar, olası tedavi seçenekleri ve riskleri konularında aydınlatır. Yapılacak aydınlatma hastanın kültürel, toplumsal ve ruhsal durumuna özen gösteren bir uygunlukta olmalıdır. Bilgiler hasta tarafindan anlaşılabilecek biçimde verilmelidir. Hastanın dışında bilgilendirilecek kişileri, hasta kendisi belirler. Sağglıkla ilgili her türlü girişim, kişinin özgür ve aydınlatılmış onamı ile yapılabilir. Alınan onam, baskı, tehdit, eksik aydınlatma ya da kandırma yoluyla alındıysa geçersizdir. Acil durumlar ile, hastanın reşit olmaması veya bilincinin kapalı olduğu ya da karar veremeyeceği durumlarda yasal temsilcisinin izni alınır." düzenlemesiyle aydınlatmanın ne şekilde yapılacağı açıklanmıştır. Aydınlatılmış onamda ise ispat külfeti hekim ya da hastanededir." denilerek bilgilendirmenin bilirkişi tarafindan uygun görünmesine rağmen davacının yapılan enjektör öncesi, enjektörün komplikasyonları konusunda bilgilendirildiğine dair aydınlatılmış onam düzenlendiğinin hekim tarafindan ispat edilememesi sebebiyle vekilin özenli davranması zorunda olduğu, en hafif kusurundan sorumlu olacağı belirtilerek uygun miktarda bir manevi tazminata hükmedilmesi gerektiğini belirterek"Yerel Mahkeme kararını bozmuştur." [16]

Yargitay 13. Hukuk Dairesi 2013/25653 Esas, 2014/7799 Karar, 19.03.2014 Tarihli kararında;

“ davacıların 1997 doğumlu çocuklarına 03.08.2010 tarihinde "triple artrodez ameliyatı" yapıldığı, tip kurallarına göre bu ameliyatın çocuklarda kemik gelişimi tamamlanmadan yapılmaması gerektiği, zira ameliyat sırasında ayak bileğindeki kıkırdakların alındığı, ayağın platinler ile sabitlendiği, kemik gelişimi tamamlanmadan yapıldığında kıkırdaklar olduğundan ameliyat edilen ayă̆ın gelişmediğini, diğer ayağa oranla kısa kaldığını belirterek maddi ve manevi tazminat davası ikame etmişlerdir. Yerel Mahkeme incelemesinde alınan bilirkişi raporları doğrultusunda " triple artrodez ameliyatının uygun endikasyon olması durumunda 12 yaş üzerinde yapılması tavsiye edilmekle, hasta kimlik bilgilerine göre ameliyat olduğu tarih de 13 yaşında olduğundan uygun endikasyon ve yaşta yapıldığı, hekime atfedilecek bir kusur bulunmadığı " görüşü belirtilmiş, Yerel Mahkeme de bilirkişi raporları kapsamında davanın reddine karar vermiştir.

Yargıtay incelemesinde "Biyotıp Sözleșmesinin 5. maddesinde "Rıza" konusu düzenlenmiş ve "Sağlık alanında herhangi bir müdahale, ilgili kişinin bu müdahaleye özgürce ve bilgilendirilmiş bir șekilde muvafakat etmesinden sonra yapılabilir. Bu kişiye, önceden, müdahalenin amacı ve niteliği ile sonuçları ve tehlikeleri hakkında uygun bilgiler verilecektir. Illgili kişi muvafakatini her zaman serbestçe geri alabilecektir.” düzenlemesiyle rızanın kapsamı belirlenmiş ve Dairemizin yerleşik uygulamalarına paralel düzenlemeler getirilmiştir. Salt yapılacak işleme rıza göstermek yeterli değildir. Ayrıca, komplikasyonların da izah edilmesi gerekmektedir. Ancak bu rızanın da az yukarıda vurgulandığı üzere aydınlatılmış rıza olması gerekir. Nitekim Hekim Etiği Yönetmeliği'nin 26. maddesinde düzenleme yapılmış ve "Hekim hastasını, hastanın sağılk durumu ve konulan tanı, önerilen tedavi yönteminin türü, başarı şansı ve süresi, tedavi yönteminin hastanın sağı̆ı̆̆ için taşıdı̆̆ı riskler, verilen ilaçların kullanılışı ve olası yan etkileri, hastanın önerilen tedaviyi kabul etmemesi durumunda hastalığın yaratacağı sonuçlar, olası tedavi seçenekleri ve riskleri konularında aydınlatır. Yapılacak aydınlatma hastanın kültürel, toplumsal ve ruhsal durumuna özen gösteren bir uygunlukta olmalıdır. Bilgiler hasta tarafindan anlaşılabilecek biçimde verilmelidir. Hastanın dışında bilgilendirilecek kişileri, hasta kendisi belirler. Sağııla ilgili her türlü girişim, kişinin özgür ve aydınlatılmış onamı ile yapılabilir. Alınan onam, baskı, tehdit, 
eksik aydınlatma ya da kandırma yoluyla alındıysa geçersizdir. Acil durumlar ile, hastanın reşit olmaması veya bilincinin kapalı olduğu ya da karar veremeyeceği durumlarda yasal temsilcisinin izni alınır." düzenlemesiyle aydınlatmanın ne şekilde yapılacağı açıklanmıştır." Denilerek ameliyat öncesi muhtemelen hâsıl olabilecek sonuç ve komplikasyonlar hakkında hastanın bilgilendirilmesinin bir zorunluluk olduğunu, dosyaya ibraz edilen bir onam belge bulunmadığını, dosya içeriğinde de hekimin hastayı ve ailesini bu konuda bilgilendirdiği ve gerekçeli açıklamaları yaparak uyardığı hususu ve davacının yeterli derecede aydınlatılıp aydınlatılmadığı, operasyonun komplikasyonlarının bilinmesi halinde dahi bu operasyona davacının rıza gösterip göstermeyeceği konuları dosya içeriği ile anlaşılamamaktadır. Hal böyle olunca bu konuda varsa davalı taraf delilleri toplanarak sonucuna göre karar verilmesi gerekirken eksik inceleme ile hüküm kurulması usul ve yasaya aykırıdır." diyerek kararı bozmuştur. ${ }^{[24]}$

Yine Ortopedi ve Travmatoloji branş alanı ile bağlantılı olmamakla birlikte "geçerli bir aydınlatılmış onam ve kapsamı açısından önemli olan" Yargıtay 13. Hukuk Dairesi 2014/46695 Esas, 2016/6790 Karar, 07.03.2016 Tarihli kararında ${ }^{[16]}$;

"Biyotıp Sözleșmesinin 5. maddesinde "Rıza" konusu düzenlenmiş ve "Sağlık alanında herhangi bir müdahale, ilgili kişinin bu müdahaleye özgürce ve bilgilendirilmiş bir şekilde muvafakat etmesinden sonra yapılabilir. Bu kişiye, önceden, müdahalenin amacı ve niteliği ile sonuçları ve tehlikeleri hakkında uygun bilgiler verilecektir. Ilgili kişi muvafakatini her zaman serbestçe geri alabilecektir." düzenlemesiyle rızanın kapsamı belirlenmiş ve Dairemizin yerleşik uygulamalarına paralel düzenlemeler getirilmiştir. Salt ameliyata rıza göstermek yeterli değildir. Ayrıca, komplikasyonların da izah edilmesi gerekmektedir. Ancak bu rizanın da az yukarda vurgulandığı üzere aydınlatılmış rıza olması gerekir. Nitekim Hekim Etiği Yönetmeliği'nin 26. maddesinde düzenleme yapılmıs ve "Hekim hastasını, hastanın sağlık durumu ve konulan tanı, önerilen tedavi yönteminin türü, başarı şansı ve süresi, tedavi yönteminin hastanın sağ/ığı için taşıdığı riskler, verilen ilaçların kullanılışı ve olası yan etkileri, hastanın önerilen tedaviyi kabul etmemesi durumunda hastalığın yaratacağı sonuçlar, olası tedavi seçenekleri ve riskleri konularında aydınlatır. Yapılacak aydınlatma hastanın kültürel, toplumsal ve ruhsal durumuna özen gösteren bir uygunlukta olmalıdır. Bilgiler hasta tarafindan anlaşılabilecek biçimde verilmelidir. Hastanın dışında bilgilendirilecek kişileri, hasta kendisi belirler. Sağlıkla ilgili her türlü girişim, kişinin özgür ve aydınlatılmış onam ile yapılabilir. Alınan onam, baskı, tehdit, eksik aydınlatma ya da kandırma yoluyla alındıysa geçersizdir. Acil durumlar ile, hastanın reşit olmaması veya bilincinin kapalı olduğu ya da karar veremeyeceği durumlarda yasal temsilcisinin izni alınır. Düzenlemesiyle aydınlatmanın ne şekilde yapılacağı açıklanmıştır. Aydınlatılmış onam da ise ispat külfeti hekim ya da hastanededir. Somut olayda, mahkemece. . .'ndan alınan 22.03.2013 tarihli raporda tonsillektomi ameliyatından sonra 4. gün gibi geç oluşan kanamalarda kanamanın sebebinin ameliyat esnasında yapılan işlemler olmayacağı, ameliyat sonrası ameliyat sahasında gelişen nekrozdan dolayı kanamaların meydana geleceği, bunun da hekim tarafindan öngörülemeyeceği kanaatinin belirtildigi, yine mahkemece, . . .'nden alınan 19.02.2014 tarihli raporda da ameliyat sonrası gerçekleşen kanamaların bu tür ameliyatların \%1'i ile \%10'u arasında oluşan komplikasyon niteliğinde olduğu, davalıların sorumluluğunun olmadığı kanaati belirtilmiştir. Mevcut durumda mahkemece alınan bilirkişi raporları ile ameliyat sonrası meydana gelen kanamaların komplikasyon niteliğinde olduğu anlaşılmakta ise de, yukarıda anlatılan bilgiler ışığında, davalıların komplikasyon sebebiyle sorumlu olmadığının kabulü için hastanın bu komplikasyon sonrası yaşadığı süreç ile ilgili ayrıntılı bir şekilde bilgilendirilmiş olması gerekmektedir. Dosya içinde bulunan 29.03.2010 tarihli "hasta onam formu" nun "ameliyatın riskleri” başlıklı bölümün a bendinde ameliyattan sonra ilk iki hafta içinde kanama oluşabileceği geç ortaya çıkan kanamalarda tekrar hastaneye yatırılarak müdahale edilebileceği, ameliyat edilebileceği ve kan kaybı sebebiyle de kan transfüzyonu gerekebileceği hususlarının açıkça yazılmış olmasına rağmen, davacının bu komplikasyon sonrası yoğun bakımda kalabileceği, să̆ tarafinı gereği gibi kullanamayabileceği, dilinin kesilip, dişlerinin sökülebileceği hususlarının formda açıkça yazılmadığı, bu durumda hastanın kanama sonrası yaşadığı să̆lık sorunları ile ilgili yeterince aydınlatılmadığı ve hasta onam formunun yukarıda anlatılan sözleşme hükümlerine göre yetersiz olduğu anlaşılmaktadır." yönünde değerlendirme yapılarak, yerel mahkemenin yeterli kabul ettiği onam formu yetersiz ve geçersiz kabul edilmiştir.

Yargıtay 13. Hukuk Dairesi 2016/7094 Esas, 2019/3740 Karar, 21.03.2019 Tarihli kararında ${ }^{[16]}$ makul süre öncesinden aydınlatma yapılmadığına vurgu yapılarak, tıbbi bilirkişi raporlarında tıbbi müdahalede bir hata olmadığının işaret edilmesinin bu açıdan tazminat sorumluluğunu engellemekle birlikte aydınlatma eksikliği nedeniyle tazminat yükümlülüğünü engellemediği gerekçesi tazminata hükmedilmesi gerektiğini belirtmiştir.

"Dosya kapsamından aydınlatmanın makul bir süre önce yapılmadığı, hastaya düşünmesi için makul bir süre verilmediği, Mahkemenin de kabulünde olduğu üzere aydınlatma yükümlülüğ̈̈nün yerine getirilmediği anlaşılmakta olup, bu yükümlülüğ̈̈n yerine getirilmemesinden her iki davalının da sorumlu olduğunun kabulü gerekir. Mahkemece, aydınlatıcı onam yükümlülügünün yerine getirilmesinden hekim ve hastanenin birlikte sorumlu olduğu kabul edilerek hâsıl olacak sonuca göre bir karar verilmesi gerekirken, aksi düşünce ile yazılı şekilde karar verilmesi usul ve yasaya aykırı olup, bozmayı gerektirir." 
Özetle; hastanın rızası alınırken aydınlatılarak bilgilendirme sürecinde bilgilendirmenin makul süre öncesinde yapılması, işleme ait risklerin hastaya mutlaka bildirilmesi hususları hukuka uygun rıza için gerekli olmanın yanında Yerleşik Yargıtay uygulamalarında özellikle dikkate alınan hususlardır ve hukuka uygun rıza için yani hukuka uygun aydınlatılmış onam varlığında ispat yükü hekim uhdesindedir.

\section{SONUÇ}

"Aydınlatılmış Onam", hasta hakkı olan "bilgilendirilme hakkı" ile hukuka uygunluk nedenlerinden olan "rıza" kavramlarının birleşmesinden oluşmaktadır. Tıbbi hata olmadığı durumlarda da hasta hakkı ihlali mevcut ise hukuka aykırılık oluşacak ve hekimlerin disiplin sorumluluğu başta olmak üzere ihlal içeren eylem sebebiyle ortaya zarar çıkması halinde tazminat hukuku ve ceza hukuku açısından sorumlulukları oluşabilecektir. Bu hususun ispat yükü hekim uhdesindedir. Hekim hastasına her türlü özen ve özveri ile gerekli tıbbi hizmeti sunmuş, hastanın hayatını kurtarmış yahut uzun süredir yaşadığı, hayat kalitesini düşüren sağlık şikâyetlerinin sona ermesini sağlamış olabilir ama bu süreç içerisinde aynı zamanda hasta hakkı ihlali olan bilgilendirme hakkına zarar verilmesi, aydınlatılmış onam bulunmadan tıbbi müdahale yapılması halinde hekimin eylemi hukuka aykırı olacaktır. Serbest irade ile aydınlatılarak bilgilendirme sonucu hastaların rızasının alınması önemlidir. Bilgilendirmenin kapsamını belirlerken özellikle risk bilgilendirmesi yapılırken gerçekleşme ihtimali olan riskin, ihtimalin sık görülen komplikasyon az görünen komplikasyon olmasından öte somut hasta için taşıdığı önem dikkate alınmalıdır. Örneğin işlem sonucunda az görünen bir komplikasyon somut hastanın özellikleri kapsamında bakıldığında o hasta için diğer kişilere istinaden daha önemli bir sonuç yaratacak ise (futbolcunun bir daha futbol oynayamaması gibi) bu bilgilendirmenin hastaya yapılması zaruridir. Son olarak, mevzuatın zorunlu tutmadığı haller dışında da hekimlerin ispat açısından somut hasta kıstasına göre yapılan aydınlatıcı bilgilendirme kapsamını gösteren metinlere süreci aktarmaları, bilgilendirme esnasında hastaya özel bilgiler ile hekime sorduğu sorular gibi hususları metne işlemeleri tavsiye edilmektedir. Kısaca, hekimin yükümlülüğü, hastanın hakkı olan hasta dosyasının en önemli tıbbi belgelerinden "aydınlatılmış onam", hekimin hastası yararına hukuka uygun rıza ile hareket ettiğini gösteren sözlü ve/veya yazılı süreçler bütünüdür.

\section{KISALTMALAR}

Biyotıp Sözleşmesi: Biyoloji ve Tıbbın Uygulanması Bakımından İnsan Hakları ve İnsan Haysiyetinin Korunması Sözleşmesi: İnsan Hakları ve Biyotıp Sözleşmesi

f.: fikra

m.: madde

s.: sayfa

TMK: Türk Medeni Kanunu

vb.: ve benzeri

Yönetmelik: Hasta Hakları Yönetmeliği

\section{KAYNAKLAR}

1. Zevkliler A, Acabey MB, Gökyayla KE. Zevkliler Medeni Hukuk Giriş - Başlangıç Hükümleri - Kişiler Hukuku - Aile Hukuku. Ankara: Seçkin Yayınevi; 6. Baskı, 1999.

2. Dural M, Öğüz T. Türk Özel Hukuku, Cilt II. Kişiler Hukuku. İstanbul: Filiz Kitabevi; 2002.

3. Oğuzman K, Barlas N. Medeni Hukuk / Giriş - Kaynaklar Temel Kavramlar. İstanbul: Beta Yayınları; 9. Baskı, 2002.

4. Türkiye Cumhuriyeti Anayasası, Kanun No: 2709, Kabul Tarihi 18.10.982. http://www.mevzuat.gov.tr/Metin1.Aspx?Mevzua tKod=1.5.2709\&Mevzuatlliski=0\&sourceXmlSearch=anayasa \&Tur=1\&Tertip=5\&No=2709 Erişim Tarihi:16.10.2019.

5. Subaşı İ. Hekimin Aydınlatma Yükümlülüğü - Aydınlatılmış Onam - Tazminat Sorumluluğu. Ankara: Seçkin Yayıncılık; 2016.

6. Madder $\mathrm{H}$. Existential Autonomy: Why Patients should make their own choices. J Med Ethics 1997;23-4:221-5. Crossref

7. Türk Medeni Kanunu. Kanun No: 4721.Kabul Tarihi: 22.11.2001. http://www.mevzuat.gov.tr/Metin1.Aspx?Mevzuat Kod=1.5.4721\&Mevzuatlliski=0\&sourceXmlSearch=medeni\%20 kanun\&Tur=1\&Tertip $=5 \& N_{0}=4721 \quad$ Erişim Tarihi: 16.10.2019.

8. Yücel Ö. Medeni Hukuk Bakış Açısıyla Tıbbi Müdahalenin Hukuka Uygunluğunun Koşulları. İçinde: Yücel Ö, Sert G, editörler. Sağlık ve Tıp Hukukunda Sorumluluk ve İnsan Hakları. Sağlık Hizmeti - Sağlık Hakkı ve Hasta Hakları Medeni Hukuk, Ceza ve İdare Hukuku Yönünden Sorumluluk. Ankara: Seçkin Yayıncılık; 2018.

9. Erman B. Ceza Hukukunda Tıbbi Müdahalelerin Hukuka Uygunluğu. Ankara: Seçkin Yayıncılık; 2003.

10. Biyoloji ve Tıbbın Uygulanması Bakımından İnsan Hakları ve İnsan Haysiyetinin Korunması Sözleşmesi: İnsan Hakları ve Biyotıp Sözleşmesinin Onaylanmasının Uygun Bulunduğuna Dair Kanun. Kanun No: 5013, Kabul Tarihi: 03.12.2003. https://www.tbmm. gov.tr/kanunlar/k5013.html Erişim Tarihi: 16.10.2019.

11. Hasta Hakları Yönetmeliği. Kanun No: 23420, Kabul Tarihi: 01.08.1998. http://www.mevzuat.gov.tr/Metin.Aspx?Mevz uatKod=7.5.4847\&Mevzuatlliski=0\&sourceXmISearch=has ta\%20haklar\%C4\%B1 Erişim Tarihi: 16.10.2019.

12. TürkBorçlarKanunu. KanunNo:6098, KabulTarihi:11.01.2011. http://www.mevzuat.gov.tr/MevzuatMetin/1.5.6098.pdf Erişim Tarihi: 16.10.2019.

13. Türk Ceza Kanunu. Kanun No: 5237, KabulTarihi: 26.09.2004. http://www. mevzuat.gov.tr/MevzuatMetin/1.5.5237.pdf Erişim Tarihi: 16.10.2019.

14. Taşcan i, Çalışkan S. Tıbbi uygulama Hataları ve Hekim Suçları. İstanbul: Yeditepe Üniversitesi Yayınevi; 2018. 
15. Tıbbi Deontoloji Tüzüğü. Bakanlar Kurulu Kararının Tarihi: 13.1.1960, No: 4/12578 Dayandığı Kanunun Tarihi: 23.1.1953, No: 6023, Yayımlandığı Resmi Gazetenin Tarihi: 19.2.1960, No: 10436. http://www.mevzuat.gov.tr/Metin1.Aspx?Mevzuat Kod=2.3.412578\&Mevzuatlliski=0\&sourceXmlSearch=deontol oji\&Tur=2\&Tertip $=3 \& N_{0}=412578$ Erişim Tarihi: 16.10.2019.

16. Kazancı İçtihat Bankası. http://www.kazanci.com/kho2/ibb/ giris.html Erişim Tarihi: 12.10.2019-14.10.2019.

17. ТТВ Aydınlatılmış Onam Kılavuzu. http://www.ttb.org.tr/ mevzuat/index.php?option $=$ com_content\&view $=$ article\&id $=983$ :onam\&catid=26:etik\&ltemid=65 Erişim Tarihi:10.10.2019.

18. Dieter G. Patient-Physician Communication and the Law's Requirements. In: Byrd BS, Hruschka J, Joerden, JC, editors, Jahrbuch für Recht und Ethik - Annual Review of Law and Ethics. Band 4 (1996), Themenschwerpunkt: Bioethik und Medizinrecht - Bioethik and the Law. Berlin: Duncker \& Humbolt; 1996. pp.273-300.

19. Hakeri H. Tıp Hukuku Temel Bilgiler, İstanbul: Seçkin Yayıncılık; 2009.
20. Hasta Haklarına illişkin Avrupa Statüsü (Ana Sözleşmesi)Temel Doküman. Roma: Kasım 2002. https://sbu.saglik.gov.tr/ hastahaklari/avrupastatusu.htm Erişim Tarihi:17.10.2019.

21. Sözmez MM, Seçkin FM, Şen B, Birgen N, Ertan A, Öztürk i. Adli Tıp Kurumu'ndan Görüş Sorulan ve Ortopedi Uzmanlık Alanına Giren Tıbbi Uygulama Hatalarının Gözden Geçirilmesi. Acta Orthop Traumatol Turc 2009;43(4):351-8. Crossref

22. Demircan A. Yüksek Riskli Ortopedik Yaralanmalar. IV. Ulusal Acil Tıp Kongresi, 08-11 Mayıs, 2008, Antalya. http://file. atuder.org.tr/_atuder.org/fileUpload/14HKp78hw72D.pdf Erişim Tarihi: 11.10.2019.

23. Sarıtaş H. Hasta Hakları Açısından Hekimin Sorumluluğu. Ankara: Bilge Yayınevi; 2005.

24. Erdem Ü. Yargıtay 13 Hukuk Dairesi (2014-2016) Kararlarında - Özel Hastane ve Hekimin Tazminat Sorumluluğu. İstanbul: Legal Yayıncılık; 2016. 